\title{
Verrucous Carcinoma of Vulva: A Report of Two Cases
}

\author{
Seema Mittal ${ }^{1}$, Shipra Singla ${ }^{2}$, Navjot Kaur ${ }^{3}$
}

\begin{abstract}
Vulvar cancer occurs in less than $1 \%$ of malignancies in women. Verrucous carcinoma of vulva is a rare histological variation occurring in less than $1 \%$ of vulvar cancer cases. It is generally locally invasive and is not associated with metastasis to distant organs. Lesions present in the form of a verrucous, ulcerated, and bleeding tumor that can reach large dimensions. The differential diagnosis is condylomata, both macroscopically and microscopically.
\end{abstract}

Keywords: Carcinoma, Histological, Surgical, Treatment, Verrucous.

AMEl's Current Trends in Diagnosis \& Treatment (2020): 10.5005/jp-journals-10055-0084

\section{INTRODUCTION}

Vulvar cancer is a rare lesion of the female genital tract. The risk factors for the pathogenesis of this tumor are human papilloma virus (HPV) infection, smoking, diabetes, and obesity. ${ }^{1,2}$ The use of oral contraceptives and vulvar cancer has not occurred primarily among older women; recent studies indicate a significant increase in the occurrence of in situ vulvar carcinomas (mainly HPV related), which usually occur in younger women. ${ }^{3-6}$

The pathogenesis is not clear yet, but recent studies postulated a role for HPV in the etiology. ${ }^{7-9}$ Additionally, the role of HPV infection has been confirmed by the detection of viral DNA in approximately $27 \%$ of verrucous carcinomas. ${ }^{10-13}$

Here, we present a report of two cases. The treatment decided in both was only surgical, i.e., wide local excision followed by flap transfer if needed.

\section{Case Descriptions}

\section{Case 1}

A 27-year-old pregnant female in her sixth months of gestation presented with chief complaint of multiple large lesions on the vulval region with pain. On examination, multiple lesions were present, largest being the ulceroproliferative growth of around $7 \times 5 \mathrm{~cm}$ present over vulva (Fig. 1), tender, foul smelling, and patient had difficulty in sitting. Wide local excision and primary closure was done. The histopathological examination confirms verrucous carcinoma. The patient recovered well postoperatively (Fig. 2).

\section{Case 2}

A 66-year-old female presented with a large lesion on vulval region. On examination, large ulcerated, fungating lesion around $5 \times 5 \mathrm{~cm}$ was present over vulva, discharging, nontender, and appeared to have invaded deeply (Fig. 3). Wide local excision followed by inferiorly based bilateral rotational flap was performed. The histopathological examination confirms the diagnosis as verrucous carcinoma. The patient recovered well postoperatively (Fig. 4).

\section{Discussion}

Verrucous carcinoma was first described in 1945 by Ackerman who reported an uncommon variant of squamous cell carcinoma.

\begin{abstract}
${ }^{1,3}$ Department of Surgery, Sri Guru Ram Das Institute of Medical Sciences and Research, Amritsar, Punjab, India

${ }^{2}$ Department of Surgery, Sri Guru Ram Das Institute of Medical Sciences and Research, Amritsar, Punjab, India

Corresponding Author: Navjot Kaur, Department of Surgery, Sri Guru Ram Das Institute of Medical Sciences and Research, Amritsar, Punjab, India, Phone: +91 9501362968, e-mail: aman.as553@gmail.com

How to cite this article: Mittal S, Singla S, Kaur N. Verrucous Carcinoma of Vulva: A Report of Two Cases. AMEl's Curr Trends Diagn Treat 2020;4(1):44-45.
\end{abstract}

Source of support: Online access

Conflict of interest: Medical researcher

Cases most commonly involve the oral cavity as well as the skin, male and female external genitalia, cervix, bladder, esophagus, and anal canal.

Verrucous carcinoma of the vulva is a slow-growing malignancy that rarely affects lymph nodes and is presented as an exophytic growth that can be locally destructive. However, if untreated, it may reach voluminous sizes that may be mistaken

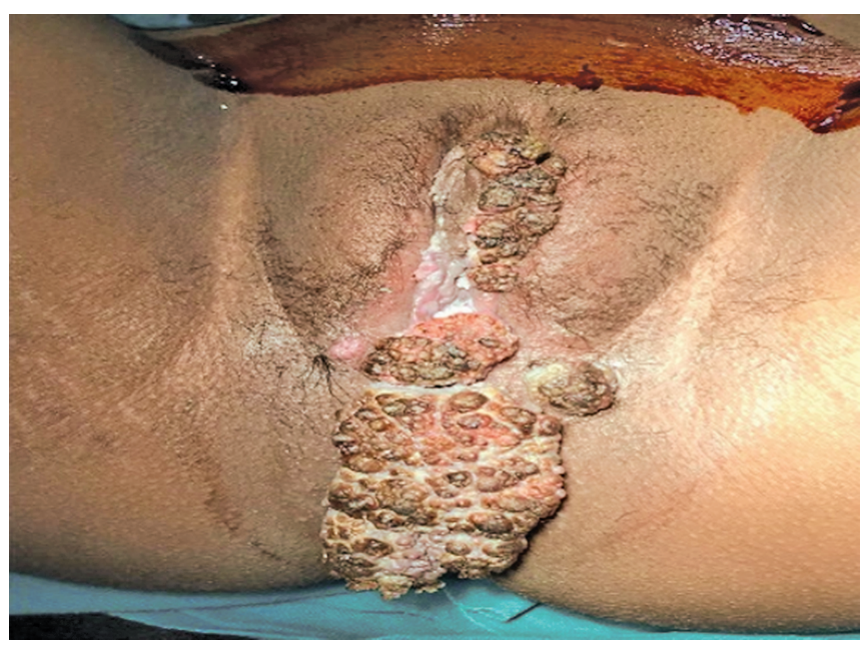

Fig. 1: Preoperative view (Case 1): Ulceroproliferative growth of around $7 \times 5 \mathrm{~cm}$ present over vulva

(c) The Author(s). 2020 Open Access This article is distributed under the terms of the Creative Commons Attribution 4.0 International License (https://creativecommons. org/licenses/by-nc/4.0/), which permits unrestricted use, distribution, and non-commercial reproduction in any medium, provided you give appropriate credit to the original author(s) and the source, provide a link to the Creative Commons license, and indicate if changes were made. The Creative Commons Public Domain Dedication waiver (http://creativecommons.org/publicdomain/zero/1.0/) applies to the data made available in this article, unless otherwise stated. 


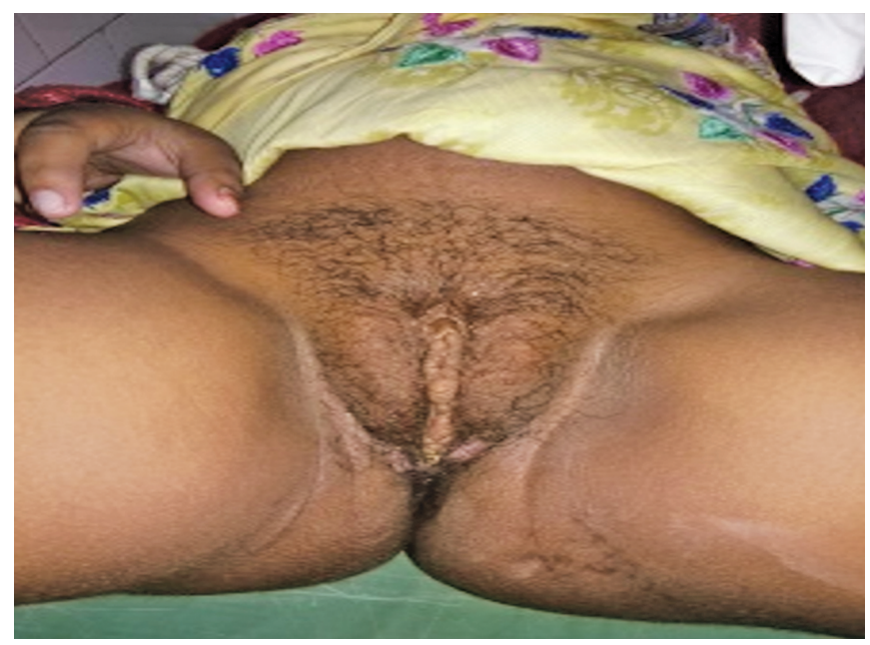

Fig. 2: Postoperative view (Case 1): Wide local excision and primary closure

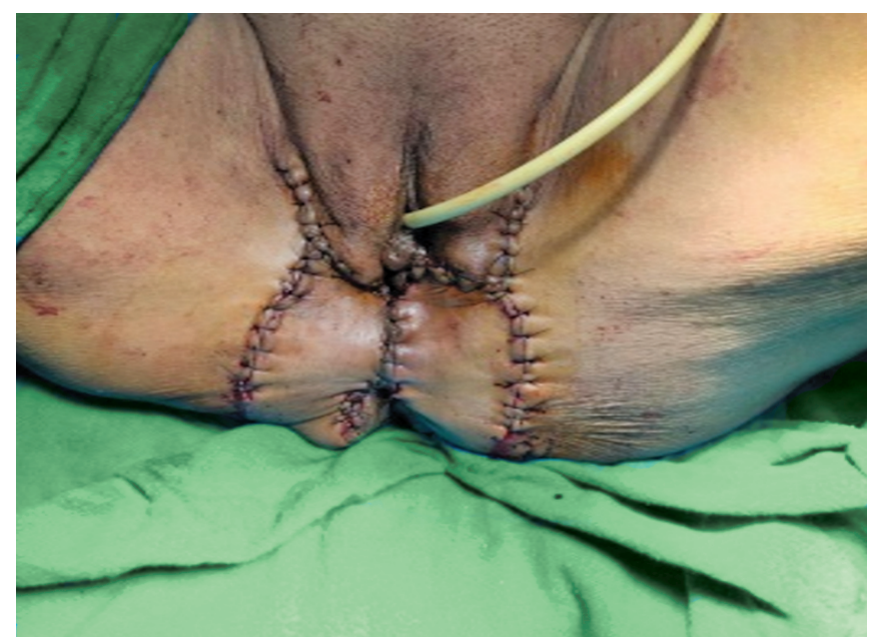

Fig. 4: Postoperative view (Case 2): Wide local excision followed by inferiorly based bilateral rotational flap

for vulvar condylomata. Therefore, this tumor classification should be kept in mind whenever a patient with condyloma does not respond to topical treatment or in cases of local ulceration. Histological diagnosis is made by tumor-dermal interface with minimal stroma between the acanthotic epithelium, minimal nuclear atypia, hyperkeratotic areas on the surface of the tumor associated with low nuclear atypia, and diffuse and chronic stromal inflammation.

Treatment should prioritize surgical procedure, which will depend on lesion size and location (surgical excision, hemivulvectomy, or vulvectomy). A free surgical margin of at least $1 \mathrm{~cm}$ should be used in order to avoid recurrences. In cases of extensive tissue resection, grafts or flaps are needed for local reconstruction.

\section{Conclusion}

Verrucous carcinoma is rare variant of squamous cell carcinoma. But it should be kept in mind in a patient presenting with large vulvar lesion. The diagnosis is confirmed by histopathological

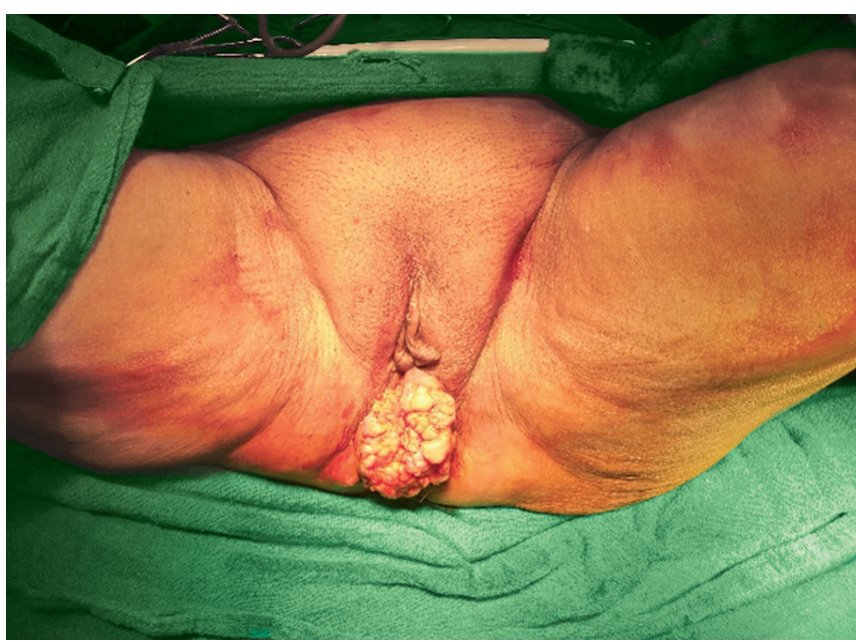

Fig. 3: Preoperative view (Case 2): Ulcerated, fungating lesion around $5 \times 5 \mathrm{~cm}$ was present over vulva

examination. Treatment is only surgical excision and closure either primary or flap/graft cover depending upon size of lesion.

\section{References}

1. Ries LAG, Melbert D, Krapcho M, et al. SEER Cancer Statistics Review, 1975-2004. Bethesda, MD: National Cancer Institute; 2004 http://Seer. Cancer.Gov/Csr/1975.

2. Brinton LA, Nasca PC, Mallin K, et al. Case-control study of cancer of the vulva. Obstet Gynecol 1990;75(5):859-866.

3. Judson PL, Habermann EB, Baxter NN, et al. Trends in the incidence of invasive and in situ vulvar carcinoma. Obstet Gynecol 2006;107(5):1018-1022. DOI: 10.1097/01.AOG.0000210268.57527.a1.

4. Bjorge T, Dillner J, Anttila T, et al. Prospective seroepidemiological study of role of human papillomavirus in non-cervical anogenital cancers. Br Med J 1997;315(7109):646-649. DOI: 10.1136/ bmj.315.7109.646.

5. Hildesheim A, Han $C L$, Brinton $L A$, et al. Human papillomavirus type 16 and risk of preinvasive and invasive vulvar cancer: Results from a seroepidemiological case-control study. Obstet Gynecol 1997;90(5):748-754. DOI: 10.1016/S0029-7844(97)00467-5.

6. Madeleine MM, Daling JR, Schwartz SM, et al. Cofactors with human papillomavirus in a population-based study of vulvar cancer. J Nat Cancer Inst 1997;89(20):1516-1523. DOI: 10.1093/jnci/89.20.1516.

7. Schwartz RA. Verrucous carcinoma of the skin and mucosa. J Am Acad Dermatol 1995;32(1):1-24. DOI: 10.1016/0190-9622(95)90177-9.

8. Majewski S, Jablonska S. Human papillomavirus-associated tumors of the skin and mucosa. J Am Acad Dermatol 1997;36(5I):659-685. DOI: 10.1016/s0190-9622(97)80315-5.

9. Miller CS, White DK. Human papillomavirus expression in oral mucosa, premalignant conditions, and squamous cell carcinoma A retrospective review of the literature. Oral Surg, Oral Med, Oral Pathol, Oral Radiol, Endodon 1996;82(1):57-68. DOI: 10.1016/s10792104(96)80378-7.

10. Tornes K, Bang G, Strømme Koppang H, et al. Oral verrucous carcinoma. Int J Oral Surg 1985;14(6):485-492. DOI: 10.1016/s03009785(85)80054-5.

11. Spiro RH. Verrucous carcinoma, then and now. Am J Surg 1998;176(5):393-397. DOI: 10.1016/s0002-9610(98)00232-3.

12. Rubio D, Moratalla E, Camarasa N, et al. Carcinoma verrucoso de vulva. Clin Invest Gin Obst 2006;33(6):241-243. DOI: 10.1016/S0210$573 \times(06) 74125-9$.

13. Yorganci A, Serinsoz E, Ensari A, et al. A case report of multicentric verrucous carcinoma of the female genital tract. Gynecol Oncol 2003;90(2):478-481. DOI: 10.1016/s0090-8258(03)00270-1. 